\title{
Ethnographies of the Opportunities and Risks of Neoliberalisation
}

\author{
By Ainhoa Montoya (Universidad Autónoma de Madrid)
}

This issue of Anthropology Matters addresses the subject of neoliberalism by enquiring into its contradictions. Rather than assuming that we are completely settled on what the term designates or that its referent is indisputably negative, we asked the contributors to this edition to consider the opportunities and risks emerging out of the processes that fall under the rubric of neoliberalism, and how these opportunities and risks are distributed within and across different populations. Our goal in doing so was to enable a better understanding of why diverse aspects of neoliberalism seem to remain dominant in spite of the crisis of neoliberal governance that surfaced in the US in mid2007 and has spread worldwide, albeit in different ways, thereafter. The grounds for this edition were laid by discussions on neoliberalism by a group of postgraduate social anthropology researchers at the University of Manchester during 2010/2011. In the context of a reading group set up to discuss David Harvey's A Brief History of Neoliberalism (2005), we raised questions revolving around the pervasiveness of neoliberalism and the possibilities for transformation through and beyond neoliberalism. These discussions led to the conceptualization of this edition of Anthropology Matters.

The bulk of scholarship addressing neoliberalism has been produced mainly by its critics and has thus rather notoriously highlighted neoliberalism's negative face (see, for instance, Arias and Goldstein 2010; Bourgois 2011; Comaroff and Comaroff 2001; Ferguson 2006; Gledhill 2004; Hale 2005; Harvey 2005; Klein 2008; Moodie 2006; 
Wacquant 2009). ${ }^{1}$ This scholarship has noted the increasing intrusion of the market in many aspects of citizenship practices at the expense of political, social, and economic rights. Far from aiming to deny or minimise neoliberalism's perils and negative impacts, the editors of this issue believe that an investigation into how neoliberalism works both perversely and seductively can provide insights into why certain aspects of neoliberalism persist, notably in the US and a number of European countries. Our use of the term 'opportunities' does not imply that benefits and perils of neoliberalism can be levelled. It is clear that neoliberalism's real opportunities and risks are unevenly distributed and incommensurable. Yet, in this issue, we would like to investigate the real and perceived benefits, however uneven or questionable, that emerge from neoliberalisation. Our ultimate goal in so doing is to yield an understanding of why political agendas including deregulation, privatisation, and the reduction of state provision have persisted and even deepened since the 2008 crisis with the consent of many, even in a context of increasing public disaffection expressed in different guises. ${ }^{2}$

Enquiring into the opportunities and risks of neoliberalism requires that we delve into what we mean by neoliberalism. The concept of 'neoliberalism' first came to prominence by proponents of the renewal of free-market liberalism, through a variegated range of formulations and viewpoints, during the first half of the twentieth century (Dean 2010: 12-13). Yet they discarded this term by the 1950s, just when their ideas were beginning to attract public attention. Coined by its critics (Peck et al. 2009:

\footnotetext{
1 An exception that underlines both the liberating and constraining elements of neoliberalisation is Freeman (2007).

2 The most notorious expressions of disaffection ensuing from the 2008 crisis ranged from the Arab Spring to the Spanish 15-M/Indignados and Occupy movements. Of course, we need to be careful not to interpret all of these as explicit protests against neoliberal policies or to place undue emphasis on the continuities between them (although some have pointed to parallels and connections; see Juris and Razsa 2012). Some have traced continuities between the mobilisations that occurred in the 1990s and 2000s and more recent expressions of dissent, for instance through political subjectivities and trajectories (see Romanos 2013). In Europe, it is clear that the more visible and articulated post-2008 crisis protests have emerged in those countries in which governments have implemented programmes of fiscal austerity in a more integral fashion.
} 
96-97), the term gained salience anew at the turn of the twenty-first century. From a perspective rooted in political economy, scholars critical of neoliberalism have employed this term to refer to practices or processes that are intricately related to the enactment of the political and ideological project of a particular class, and that have triggered substantial state transformation (Brand and Sekler 2009: 6; Harvey 2005; Peck and Tickell 2002). Foucauldian scholars, for their part, have invoked the term 'neoliberalism' to denote both an intellectual movement with a common - albeit incoherent - framework and a set of technologies of government that regulate the self through authority, as much as through freedom (Dean 2010: 11, 15).

There has been nonetheless extensive debate about whether the term is a misnomer, or is even analytically useful at all (see for instance Clarke 2008). The 2012 debate held at Manchester as part of the Group of Debates in Anthropological Theory (GDAT) ${ }^{3}$ was an example of such controversy around the term neoliberalism. Opponents of the term suggested that it should be dropped altogether: its all-encompassing nature - as an analytical concept defining everything that has occurred in the political realm since the 1980s and eliding empirical diversity - and the moral charge conferred to it by its critics have ultimately obscured its meaning. Proponents of the term, meanwhile, made a plea for its significant analytical value in the contemporary world. Without claiming that neoliberalism manifests the same way everywhere, they argued that the term defines the degree of coherence characterising worldwide tendencies and processes of a political-economic nature while enabling comparison across regions and populations.

The editors and authors of this issue consider the term neoliberalism helpful as an analytical tool with which to shed light on particular contemporary socioeconomic phenomena that share a familiarity or even patterned forms. 'Neoliberalism' is addressed in this issue as a form of governance contingent to the recent history of capitalism and developed through manifold socio-spatial processes. These processes

\footnotetext{
${ }^{3}$ To listen to the full audio recording of this debate, visit http://www.talkinganthropology.com/2013/01/18/ta45-gdat1-neoliberalism/ - t=00:28.745
} 
have facilitated an increasing imbrication of citizenship practices and the market sphere while yielding a new common sense that naturalises their imbrication. The authors have resorted to, and at times combined, what sociologist Loïc Wacquant (2012: 68-70) characterised as the two existing anthropological approaches to neoliberalism: marketcentred and structural analyses on the one hand and theories of governmentality and the self on the other. The approaches to neoliberalism represented in this issue vary significantly, ranging from a focus on local entrepreneurial elites (Laura Jordan) and an examination of regulatory techniques of a global nature (Susanne Hofmann and Andrew Hodges) to an emphasis on the outcomes of flexible accumulation and the unevenness of neoliberalisation (Andrew Hodges), and an analysis of neoliberalism's discursive dimension and the politics around it (Mike Upton). These are not incompatible approaches; on the contrary, the range of approaches the articles offer points to the hybrid, unfinished, and ambiguous nature of neoliberalism, existing necessarily in articulation with other worldviews and practices. The articles thus illuminate important aspects of how neoliberalism - as an ideology and as a government project - intersects with and traverses personal modes of conduct. Indeed, all four articles underline the role played by 'common sense' in legitimising neoliberal policies or signifying their aspects as opportunities.

\section{Is It Time We Talked about Post-Neoliberalism?}

Even as debates continue about what exactly is meant by neoliberalism, what is new about it relative to prior versions of liberalism, and the analytical utility of the term, some have begun to suggest that we might be entering a post-neoliberal phase. The Latin American region is considered to epitomise these post-neoliberal tendencies (see Hershberg and Rosen 2006; Macdonald and Ruckert 2009; Sader 2009). The proliferation of governments self-categorised as leftwing in various Latin American countries at the turn of the twenty-first century, along with attempts by these governments to challenge the hegemony of neoliberalism, are considered by some to be a prelude to neoliberal policies' loss of legitimacy. In a similar vein, since the onset of 
the 2007/2008 financial crisis, public discussion has arisen about the prospect that the daunting dimensions of this crisis and the concomitant discrediting of neoliberal policies might facilitate the development of new alternatives (Peck et al. 2009).

References to the crisis and even the death of neoliberalism have invoked an understanding of neoliberalism as a monolithic and static system or structure (Peck et al. 2009: 101). Yet, neoliberalism is far from a singular phenomenon and would indeed be more accurately described as a set of processes, these "conceived as an hegemonic restructuring ethos, as a dominant pattern of (incomplete and contradictory) regulatory transformation, and not a fully coherent system or typological state form" (Peck et al. 2009: 104). As various scholars have underlined, processes of transnational neoliberalisation have developed unevenly (Harvey 2005; Peck 2004) and embedded in processes of a very different nature (Collier 2011; Ong 2006; Peck et al. 2009: 104; Willis et al. 2008: 234-237). It would thus be counterintuitive to speak of neoliberalism's sudden and global demise. Yet so would be the prospect of a unified and overarching alternative (Sekler 2009). Some scholars have suggested that rather than being at a terminal stage, neoliberalism may have entered a 'zombie phase' whereby it is sustained by macroeconomic and macroinstitutional conditions yet no longer intellectually or morally hegemonic (Laval and Dardot 2013: 13; Peck et al. 2009: 105, 112; Peck 2010). In this regard, the term 'post-neoliberalism' might prove a useful analytical perspective from which to cautiously account for the delegitimation of certain aspects of neoliberalism within specific regions and groups (Brand and Sekler 2009: 6-7; Grugel and Riggirozzi 2012).

However, as important as it is to acknowledge the challenges and emerging alternatives to neoliberalism, as well as its adjustments throughout time, it is also crucial to enquire about the agents and forces that are enabling the persistence and revamping of core normative aspects of neoliberal agendas as laid out in the 1980s and 1990s. ${ }^{4}$ Indeed, a few years after the onset of the 2007/2008 crisis, policies in a large part of the Global

\footnotetext{
${ }^{4}$ I thank Ellen Moodie (personal communication 2012) for her reminder that we need to emphasise that neoliberalism is a 'shifting target,' clearly varying today from how it was practised in previous decades.
} 
North have been oriented towards a rapid makeover, stabilisation of credit markets, and restoration of growth rather than a radical rethinking of political agendas and an acknowledgement of how neoliberal policies lay at the roots of the crisis. Meanwhile, large segments of populations have not participated in the protests and other manifestations of discontent that have ensued from the crisis. It may be, as some have pointed out, that it is the very absence of a clear, global alternative that underlies neoliberalism's continued dominance (Peck et al 2009: 102-103; Peck et al. 2012). Yet, in this Anthropology Matters issue we urge readers to consider the wide variety of opportunities - real or perceived - that neoliberalism has offered and continues to offer to specific populations. An analysis of these opportunities, we believe, might partly explain why, in the immediate aftermath of the 2007/2008 crisis, there has not been a more prominent contestation of specific elements of neoliberal agendas or a more clearly articulated desire for alternatives.

\section{Opportunities and Risks of Neoliberalisation}

In this issue of Anthropology Matters, we have brought together four articles that make the case for approaching neoliberalism as a transnational phenomenon, albeit one that manifests through situated practices and histories. The four articles are based on extensive research in very different regions and realms, with research methods ranging from multi-sited ethnography to semi-structured interviews to analysis of media and other secondary sources. The contributors to this issue have characterised neoliberalism through the 2007/2008 global financial crisis, and through various processes: deindustrialisation; the weakening of labour protections; fiscal policies of regressive redistribution; the privatisation of public assets and severe cuts in state spending; the unfettered primacy of the private sector, enabled by the co-existence of deregulation and legal formalism; the development of 'audit cultures;' the promotion of individual projects underpinned by managerialism and consumption-centred rationales; flexible accumulation and the attendant reorganisation of labour, capital, and information; and the marketisation of an ever-increasing number of domains, including the production of 
knowledge itself. While these practices and processes might not all be essentially neoliberal, it is their combination and convergence that characterises neoliberalism (Clarke 2008: 141). More relevant to this issue, although all the articles emphasise the negative connotations of neoliberalisation and its effects, they simultaneously seek to unravel opportunities, whether real or perceived, that might emerge out of neoliberalisation in specific contexts.

The scholarship on neoliberalism has generally maintained that neoliberal agendas have, since the $1980 \mathrm{~s}$, contributed to a dramatic rise in the profit rates of financial corporations, thereby concentrating capital in the hands of an increasingly small elite (Duménil and Lévy 2004; Harvey 2005: 16-19). Laura Jordan's article speaks to this scholarship by exploring how local elites in the US have responded to the challenges and opportunities of neoliberalisation. Specifically, she examines how elites affiliated with the General Motors automobile corporation in Flint, Michigan - after being negatively impacted by the neoliberal policies enacted by global elites during the $1980 \mathrm{~s}$ - subsequently pursued small-scale neoliberal practices themselves that would allow them to make a significant profit. These local elites employed their lobbying abilities in order to secure public, non-for-profit funds for their own for-profit developments while presenting these as philanthropic efforts. As a result, working classes have become more vulnerable and ethno-racial hierarchies have been reinforced. Overall, while essentially acknowledging that neoliberalism has fundamentally benefited elites globally, Jordan underlines an important nuance: neoliberalism has not benefited elites evenly. Even more crucially, her article describes how profits made by local elites have largely relied on public funds and services.

The remaining three articles explore realms less frequently addressed in studies acknowledging opportunities that have emerged out of neoliberalisation processes. These opportunities include the upward social mobility, autonomy and empowerment of sex workers in Tijuana, Mexico, at the turn of the twenty-first century (Susanne Hofmann); the increased support and funding received by scientists within post-Fordist regimes of flexible accumulation (Andrew Hodges); and the possibilities for social 
justice endeavours opened up by the transnational 'harmonisation' of intellectual property law, especially as it pertains to the access to medicines for the treatment of HIV/AIDS (Mike Upton). In contrast to Jordan's article, these three pieces portray circumstances that are not necessarily positive tout court for the particular group in question, and whose opportunities are not automatic outcomes of neoliberalisation processes or come with attendant limitations and perils.

Studies of neoliberal governmentality have highlighted how neoliberalism works through regulatory techniques that act upon individuals through discourses and practices of freedom rather than coercion and discipline (see, for instance, Rose 1999). Susanne Hoffman's piece builds upon this literature to argue that the investigation of the workings of neoliberal governmentality in the context of Tijuana's sex industry sheds light on the freedoms and limitations that emerge out of the entanglement of the aspirations of individuals with the demands of the market. Women who sell sex at the US-Mexico border have found beneficial the shift from personalistic to managerial sex work arrangements that occurred at the end of the twentieth century. Yet, even as they celebrate the opportunities that self-employment offers for self-determination (vis-à-vis issues such as money handling, work schedule, and choice of clients or venues) and upward social mobility, Hoffman suggests that these women are able to enjoy only a 'precarious agency' given the limitations and risks - largely related to their subjection to market logics - that Tijuana's sex industry continues to impose upon them.

The third article in this issue portrays the geographical unevenness that characterises processes of neoliberalisation (see Harvey 2005: 87-119). Andrew Hodges argues that although neoliberal policies and modes of governmentality did not find their way to Serbia until the twenty-first century, neoliberalisation has had an impact in this postsocialist country nonetheless. A 'knowledge economy' has developed globally that has placed scientific innovation at the service and pace of markets that were increasingly shifting to models of flexible accumulation. While this process has yielded opportunities for scientists around the world to pursue swift cutting-edge innovations and to secure generous funding, these opportunities have not been distributed evenly. 
Serbian astrophysicists, for instance, have harboured the feeling of lagging behind technologically due, on the one hand, to the international sanctions imposed on them during the 1990s and, on the other, to their inability to keep pace with the accelerated technological innovation and capital circulation enjoyed by capitalist centres. Against this background, Hodges observes that, in the late 2000s, Serbian astrophysicists in Belgrade have consistently invoked their sense of belonging to a supranational 'scientific community' as a means of overcoming the isolation they have experienced. Hodges's ethnography, in short, illustrates how this segment of Serbian scientists aspires to benefit from the opportunities offered by neoliberalisation - opportunities from which they have thus far been excluded.

This issue closes with a discussion of how essentially neoliberal concepts and practices can be redeployed to problematise and counter their own neoliberal foundations. Drawing from fieldwork at an international organisation representing the interests of the Global South, Mike Upton's article explores processes related to the transnational 'harmonisation' of intellectual property law - specifically as it pertained to access to antiretroviral drugs - during the late 2000s. Although international patent regulation is flexible enough to allow manufacturers other than patent-holders to produce patentprotected products, the production of cheaper generic anti-HIV/AIDS drugs in the Global South has been effectively sanctioned. In this context, Upton describes how Global South advocates have developed a 'knowledge ecology' paradigm that challenges the globally dominant 'knowledge economy' described in Hodges' article. While likewise employing the semantics of patents, the 'knowledge ecology' paradigm is construed through a language that metaphorically invokes Nature and the exploitative bioprospecting activities of the Global North as a means to negatively frame and critique the deleterious activities of international pharmaceuticals. In this sense, Upton's argument is consistent with those asserting that challenges to pervasive neoliberalisation processes are emerging in articulation with neoliberal logics and concepts rather than in outright opposition to them (see, for instance, Greenhouse 2010: 4; North 2008; Willis et al. 2008: 2). 
The contributions to this issue of Anthropology Matters make a case for the continued relevance of the subject of neoliberalism, notwithstanding the scholarship that increasingly questions the usefulness of this term as an analytical tool or considers its referent to have been largely overcome by the emergence of post-neoliberal governments and processes. They do so by illuminating the substance of processes of neoliberalisation that otherwise seem largely abstract. While each article focuses on a particular context, they all indicate that the opportunities of neoliberalisation are unevenly distributed and, indeed, as it has been widely emphasised by the scholarship on the subject, that increasing inequality has been one of the most notorious outcomes of neoliberalisation. Some of the articles highlight how neoliberal agendas shape the aspirations of individuals, even when opportunities are accompanied by risks and limitations or do not materialise at all, so that it is not simply elites that are supportive of particular aspects of neoliberalisation. Interestingly, as indicated by the last article in this edition, some of the opportunities offered by neoliberalisation have themselves engendered possibilities for challenging neoliberalism. In sum, we hope this issue will promote discussion on what may be inhibiting or advancing a more forceful movement beyond neoliberalisation and towards more just social contracts.

\section{About the Author}

Dr Ainhoa Montoya received her PhD in Social Anthropology from the University of Manchester. She has held postdoctoral positions at the University of London and Universidad Autónoma de Madrid. Her research has focused on Salvadorans' remaking of political subjectivities in a context of routine post-conflict violence and concurrent political and economic liberalisation. 


\section{Acknowledgements}

I thank Jonathan Mair, Ernesto García López, Čarna Brković and Rachel Wilde for their invaluable suggestions and comments. I assume full responsibility and apologise for any misinterpretations of the work of others. As former editor of Anthropology Matters, Aliaa Remtilla had a central role in the conceptualisation of this issue. Čarna Brković, who joined the Anthropology Matters editorial team in 2013, likewise provided important input during the last stages of this issue's editorial process. The publication of this issue would not have been possible without the immense volunteered work of various anonymous reviewers, of copy-editors Catherine Baker and Bryonny Goodwin-Hawkins, and of proof-reader Helena Dembsky.

\section{References}

Arias, Enrique D. and Daniel M. Goldstein (eds.). 2010. Violent Democracies in Latin America. Durham, NC: Duke University Press.

Bourgois, Philippe. 2011. 'Lumpen Abuse: The Human Cost of Righteous Neoliberalism,' City \& Society 23(1), 2-12.

Brand, Ulrich and Nicola Sekler. 2009. 'Postneoliberalism: Catch-All Word or Valuable Analytical and Political Concept? - Aims of a Beginning Debate,' Development Dialogue 51, 5-13.

Clarke, John. 2008. 'Living With/In and Without Neo-Liberalism,' Focaal-European Journal of Anthropology 51, 135-47.

Collier, Stephen J. 2011. Post-Soviet Social: Neoliberalism, Social Modernity, Biopolitics. Princeton, NJ: Princeton University Press. 
Comaroff, Jean and John L. Comaroff (eds.). 2001. Millennial Capitalism and the Culture of Neoliberalism. Durham, NC: Duke University Press.

Dean, Mitchell. 2010. A Response to the Questions: What is Neoliberalism?, Etcetera. Paper presented at the Workshop Contesting Neoliberalism and Its Future, University of Sydney. http://sydney.edu.au/arts/political_economy/downloads/Mitchell_Dean.pdf (accessed 8 December 2012).

Duménil, Gérard and Dominique Lévy. 2004. Capital Resurgent: Roots of the Neoliberal Revolution. Cambridge, Mass. and London: Harvard University Press.

Ferguson, James. 2006. Global Shadows: Africa in the Neoliberal World Order. Durham, NC: Duke University Press.

Freeman, Carla. 2007. 'The “Reputation” of Neoliberalism', American Ethnologist 34(2), 252-267.

Gledhill, John. 2004. 'Neoliberalism', in David Nugent and Joan Vincent (eds.). A Companion to the Anthropology of Politics, 332-348. Malden, MA and Oxford: Blackwell Publishing.

Greenhouse, Carol J. (ed.). 2010. Ethnographies of Neoliberalism. Philadelphia: University of Pennsylvania Press.

Grugel, Jean and Pía Riggirozzi. 2012. 'Post-neoliberalism in Latin America: Rebuilding and Reclaiming the State after Crisis,' Development and Change 43(1), 121. 
Hale, Charles. 2005. 'Neoliberal Multiculturalism: The Remaking of Cultural Rights and Racial Dominance in Central America,' PoLAR: Political and Legal Anthropology Review 28(1), 10-28.

Harvey, David. 2005. A Brief History of Neoliberalism. Oxford: Oxford University Press.

Hershberg, Eric and Fred Rosen. 2006. Latin America after Neoliberalism: Turning the Tide in the $21^{\text {st }}$ Century? New York and London: The New Press.

Juris, Jeffrey and Maple Razsa. 2012. 'Occupy, Anthropology, and the 2011 Global Uprisings,' Cultural Anthropology [online]. http://www.culanth.org/fieldsights/63occupy-anthropology-and-the-2011-global-uprisings (accessed 18 May 2014).

Klein, Naomi. 2008. The Shock Doctrine: The Rise of Disaster Capitalism. London: Penguin.

Laval, Christian and Pierre Dardot. 2013. La nueva razón del mundo. Ensayo sobre la sociedad neoliberal. Barcelona: Editorial Gedisa.

Macdonald, Laura and Arne Ruckert. 2009. Post-Neoliberalism in the Americas. Basingstoke: Palgrave Macmillan.

Moodie, Ellen. 2006. 'Microbus Crashes and Coca-Cola Cash: The Value of Death in “Free-Market” El Salvador,' American Ethnologist 33(1), 63-80.

North, Pete. 2008. 'Voices from the Trueque: Barter Networks and Resistance to Neoliberalism in Argentina,' in Adrian Smith, Alison Stenning, and Katie Willis (eds.). Social Justice and Neoliberalism: Global Perspectives, 16-38. London: Zed Books. 
Ong, Aihwa. 2006. Neoliberalism as Exception: Mutations in Citizenship and Sovereignty. Durham and London: Duke University Press.

Peck, Jamie. 2004. 'Geography and Public Policy: Constructions of Neoliberalism,' Progress in Human Geography 28(3), 392-405.

Peck, Jamie. 2010. 'Zombie Neoliberalism and the Ambidextrous State,' Theoretical Criminology 14(1), 1-7.

Peck, Jamie and Adam Tickell. 2002. 'Neoliberalizing Space,' Antipode 34(3), 380404.

Peck, Jamie, Nick Theodore and Neil Brenner. 2009. 'Postneoliberalism and Its Malcontents,' Antipode 41(6), 1236-1258.

Peck, Jamie, Nick Theodore and Neil Brenner. 2012. 'Neoliberalism Resurgent? Market Rule after the Great Recession,' The South Atlantic Quarterly 111(2), 265-288.

Romanos, Eduardo. 2013. 'Collective Learning Processes within Social Movements: Some Insights into the Spanish 15M/Indignados Movement,' in Cristina Flesher Fominaya and Laurence Cox (eds.). Understanding European Movements: New Social Movements, Global Justice Struggles, Anti-Austerity Protest, 203-19. Routledge

Rose, Nikolas. 1999. Governing the Soul: The Shaping of the Private Self. London: Free Association Books.

Sader, Emir. 2009. 'Postneoliberalism in Latin America,' Development Dialogue, 51, 171-179.

Sekler, Nicola. 2009. 'Postneoliberalism From and As a Counter-Hegemonic Perspective,' Development Dialogue 51, 59-71. 
Wacquant, Loïc. 2009. Punishing the Poor: The Neoliberal Government of Social Insecurity. Durham and London: Duke University Press.

Wacquant, Loïc. 2012. 'Three Steps to a Historical Anthropology of Actually Existing Neoliberalism,' Social Anthropology 20(1), 66-79.

Willis, Katie, Adrian Smith, and Alison Stenning. 2008. 'Introduction: Social Justice and Neoliberalism,' in Adrian Smith, Alison Stenning, and Katie Willis (eds.). Social Justice and Neoliberalism: Global Perspectives, 1-15. London: Zed Books. 